\title{
Faktor-faktor yang Berhubungan dengan Pemberian Asi Satu Jam Pertama Setelah Melahirkan
}

\author{
Setiyowati Rahardjo*
}

\begin{abstract}
Abstrak
Di Indonesia, Angka Kematian Bayi (AKB) masih yang tertinggi di negara-negara ASEAN. Penyebab utama kematian anak balita tersebut adalah penyakit infeksi saluran nafas dan diare yang dapat dicegah antara lain dengan pemberian ASI secara benar dan tepat. Pada periode 2002-2003, sekitar 95,9\% balita sudah mendapat ASI, tetapi hanya $38,7 \%$ balita mendapat ASI pertama satu jam setelah lahir. Tujuan penelitian ini adalah untuk mengetahui berbagai faktor yang berhubungan dengan pemberian ASI dalam satu jam pertama setelah melahirkan. Penelitian ini menggunakan sumber data sekunder SDKI 2002-2003 dengan desain cross sectional. Sampel berjumlah 6.018 terdiri dari ibu yang memiliki anak berusia 0 - 24 bulan terakhir yang masih hidup dan dilahirkan tanpa operasi dan mendapat ASI. Analisis data dilakukan dengan model regresi logistik multivariat. Ditemukan proporsi pemberian ASI satu jam pertama setelah melahirkan adalah $38,3 \%$. Faktor dominan yang berhubungan dengan pemberian ASI dalam satu jam pertama adalah tenaga periksa hamil. Faktor lain adalah daerah tempat tinggal, kehamilan diinginkan, tenaga periksa hamil, penolong persalinan, akses terhadap radio, dan berat lahir. Terdapat interaksi antara daerah dengan tenaga periksa, kehamilan diinginkan dengan tenaga periksa, dan berat lahir dengan penolong persalinan. Perlu upaya meningkatkan pengetahuan dan motivasi petugas kesehatan mengenai pentingnya ASI segera dan ASI eksklusif, upaya peningkatan pengetahuan ibu dan calon ibu mengenai tata laksana pemberian ASI yang benar serta program keluarga berencana.
\end{abstract}

Kata kunci : ASI satu jam pertama, faktor risiko, SDKI 2002 - 2003.

\begin{abstract}
Infant Mortality Rate (IMR) in Indonesia is still the highest among the other ASEAN countries. The major cause for infant and children mortality is infections, especially the upper respiratory tracts infection and diarrhea. The prevention efforts for reducing the infections are a good nutrition management for infant and children such as adequate and appropriate breastfeeding. A good start for breastfeeding is about 30 minutes after delivery. The Indonesia DHS 2002-2003 showed that $95.5 \%$ children under five have already have breast-milk, but only $38.7 \%$ of them are having the first breast-milk within one hour after delivery. The Objective of this study is to know the factors related to the breastfeeding given within one hour after delivery. The study uses secondary source of data of the Indonesia DHS $2002-2003$ with a cross-sectional design. The number of sample is 6.018 , which are mothers who have the latest life child aged 0 to 24 months and still having breastfed and delivered without surgery. Data are analyzed using the application multivariate logistic regression. The study has found that the proportion of breastfeeding given within one hour after delivery as high as $38.28 \%$. The dominant factor related to the breastfeeding given within one hour after delivery is the antenatal care provider. Other factor are: the residential location, wanted pregnancy, the antenatal care provider, birth attendance, accessibility on radio, and newborn's weight. There is an interaction between residential location and the antenatal care provider, wanted pregnancy and the antenatal care provider, and newborn's weight and the birth attendance. There is a need to make an effort on: increasing the knowledge and motivation for the health provider about the importance of the immediate administration of breastfeeding to the newborn and the exclusive breastfeeding. The efforts should be supported by government policy.
\end{abstract}

Key words : Breastfed in first one hour, risk factor, IDHS 2002-2003.

* Staf Pengajar Program Sarjana Kesehatan Masyarakat Universitas Jenderal Soedirman, Purwokerto 
Angka Kematian Bayi (AKB) adalah indikator status kesehatan yang peka menerangkan derajat kesehatan masyarakat. Salah satu masalah kesehatan utama di Indonesia adalah masih tingginya angka kematian bayi (35 per seribu kelahiran hidup). ${ }^{1}$ AKB di Indonesia masih tergolong tinggi dibandingkan negara ASEAN lain. Data World Factbook tahun 2003, menunjukkan AKB Philipina 24,98 per 1000 kelahiran hidup (KH), Thailand 21,83 per $1000 \mathrm{KH}$, Malasyia 19 per $1000 \mathrm{KH}$, Brunei Darussalam 13,5 per $1000 \mathrm{KH}$, dan Singapura 3,3 per $1000 \mathrm{KH}^{2}$ Penyebab utama kematian bayi dan balita di Indonesia adalah penyakit infeksi terutama infeksi saluran nafas dan diare. Proporsi kematian bayi karena infeksi saluran nafas adalah sebesar $27,6 \%$ dan merupakan peringkat kedua setelah gangguan perinatal, peringkat ketiga adalah diare dengan proporsi 9,4\%. Proporsi kematian balita karena infeksi saluran nafas adalah sebesar $22,8 \%$ dan diare peringkat kedua dengan 13,2\%.3

Upaya pencegahan terhadap penyakit infeksi dapat dilakukan dengan keadaan gizi balita yang baik. Pemeliharaan gizi bayi dan balita yang baik memerlukan pengaturan makanan yang tepat yaitu salah satunya dengan pemberian ASI secara benar dan tepat. ${ }^{4}$ Bayi yang mendapat ASI akan lebih terjaga dari penyakit infeksi terutama diare dan ISPA serta mempunyai peluang untuk hidup lebih baik dibandingkan dengan bayi yang mendapat susu formula. 5,6 Air Susu Ibu memegang peranan penting untuk menjaga kesehatan dan kelangsungan hidup bayi. Awal menyusui yang baik adalah 30 menit setelah bayi lahir karena dapat merangsang pengeluaran ASI selanjutnya, disamping itu akan terjadi interaksi atau hubungan timbal balik dengan cepat antara ibu dengan bayi. ${ }^{7}$

Kontak awal dan menyusui sedini mungkin mempunyai banyak keuntungan. Interaksi segera antara ibu dan bayi dalam beberapa menit setelah kelahiran berhubungan erat dengan kesuksesan menyusui dan merupakan alternatif untuk mencegah pemberian makanan/minuman pralaktal. Ibu yang memberikan ASI dalam satu jam pertama setelah melahirkan mempunyai peluang 2 sampai 8 kali lebih besar untuk memberikan ASI eksklusif sampai 4 bulan dibandingkan dengan ibu yang tidak. ${ }^{8}$ Ibu yang segera kontak dan menyusui mempunyai potensi $50 \%$ lebih lama waktu menyusuinya dan lebih sedikit bayi yang terkena penyakit infeksi. ${ }^{9}$ Isapan bayi segera setelah persalinan sangat menguntungkan karena dapat mempercepat pelepasan plasenta dan mencegah perdarahan postpartum, ${ }^{10}$ serta bayi akan mendapatkan kolostrum. ${ }^{11}$ Pemberian ASI sedini mungkin (satu jam pertama) sangat besar manfaatnya bagi bayi. Akan tetapi sangat disayangkan masih banyak para ibu yang menunda inisiasi ASI. Hasil Survei Demografi dan Kesehatan Indonesia 2002-2003 menunjukkan 95,9\% balita sudah mendapat ASI dan dari jumlah ini hanya 38,7 \% balita mendapat ASI pertama dalam 1 jam setelah lahir.

Penelitian ini bertujuan untuk mengetahui gambaran pemberian ASI dalam satu jam pertama dan faktor-faktor apa sajakah yang berhubungan dengan pemberian ASI dalam satu jam pertama setelah melahirkan berdasarkan data SDKI $2002-2003$.

\section{Metode}

Penelitian ini menggunakan sumber data sekunder Survei Demografi dan Kesehatan Indonesia (SDKI) tahun 2002-2003. Responden pada penelitian ini adalah ibu usia 15-49 tahun dan memiliki anak terakhir usia 0-24 bulan yang masih hidup. Sebagai unit analisis adalah anak balita terakhir yang masih hidup berusia 0-24 bulan, mendapat ASI dan dilahirkan tanpa operasi. Dengan rumus besar sampel uji hipotesis beda proporsi dua sampel didapatkan 6018 sampel.

Analisis data meliputi analisis univariabel untuk menggambarkan karakteristik masing-masing variabel. Analisis penelitian ini memperhitungkan tehnik pengambilan sampel secara klaster sehingga data hasil penelitian ini disajikan dengan memperhitungkan bobot pada setiap variabelnya. Selain itu disajikan pula nilai desain efek (Deff), yaitu perbandingan varians yang diperoleh pada desain sampel yang kompleks dengan varians yang diperoleh jika survei tersebut dilaksanakan dengan desain sampel acak sederhana (simple random sampling/SRS) dan nilai ROH (Rate Of Homogenity) yaitu derajat kesamaan sampel di dalam klaster dibandingkan derajat kesamaan antar klaster. Pada umumnya nilai $\mathrm{ROH}$ berkisar antara 0 dan 1 . Semakin mendekati satu berarti masalah/hasil semakin homogen di dalam klaster dan semakin bervariasi antar klaster.

Analisis bivariabel dengan regresi logistik sederhana, dan analisis multivariabel dengan regresi logistik multivariat. Dalam penelitian ini pemberian ASI untuk pertama kali dikelompokkan menjadi dua yaitu pemberian ASI $\leq 1$ jam pertama setelah melahirkan dan pemberian ASI $>1$ jam pertama setelah melahirkan.

\section{Hasil}

Rata-rata ibu yang menjadi responden berada pada usia reproduksi sehat dan umur ibu sangat bervariasi di dalam desa/kelurahan $(r o h=0,09)$ atau hampir sama di antara desa-desa/kelurahan. Jumlah anak yang dilahirkan antara $2-3$ orang dan cukup bervariasi di dalam desa (roh=0,18). Berdasarkan tingkat pendidikan, persentase ibu yang berpendidikan tinggi dan pendidikan rendah tidak terlalu jauh berbeda, demikian juga dengan tingkat pendidikan suami. Pendidikan ibu dan pendidikan suami ini bervariasi di dalam desa/kelurahan (roh $=0,2$ dan roh=0,26). Lebih dari tiga perempat ibu menyatakan bahwa kehamilannya memang diinginkan dan sangat bervariasi di dalam desa/kelurahan (roh=0,07). Berdasarkan daerah tempat tinggal persentase ibu yang tinggal di pedesaan maupun di perkotaan tidak berbeda 
jauh.

Akses terhadap media yang meliputi media massa (koran), media radio, dan media televisi menunjukkan bahwa sebagian besar ibu mempunyai akses terhadap media koran yang kurang baik dengan penyebaran yang sangat bervariasi di dalam desa/kelurahan (roh=0,07), kurang lebih tiga perempat ibu mempunyai akses terhadap radio yang kurang baik dan kondisi ini cukup bervariasi di dalam desa $(r o h=0,18)$. Lebih dari setengah ibu mempunyai akses terhadap televisi yang baik, kondisi ini cukup bervariasi di dalam desa $(r o h=0,17)$.

Persentase ibu berdasarkan tenaga periksa hamil menunjukkan sebagian besar ibu melakukan pemeriksaan kehamilan dengan tenaga kesehatan, keadaan ini bervariasi di dalam desa/kelurahan $(r o h=0,24)$. Masih terdapatnya ibu yang tidak melakukan periksa hamil menunjukkan kurangnya kesadaran ibu untuk memeriksakan kehamilannya. Hal yang sama juga terlihat pada persentase ibu berdasarkan tempat periksa hamil yaitu sebagian besar ibu melakukan pemeriksaan kehamilan ke fasilitas kesehatan dan penyebaran tempat periksa hamil lebih bervariasi di dalam desa/kelurahan (roh $=0,16)$.

Masih cukup banyak ibu yang persalinannya ditolong petugas non kesehatan walaupun sebagian besar ibu melakukan periksa hamil dengan petugas kesehatan. Lebih dari setengah ibu melahirkan bayinya di rumah. Penyebaran penolong persalinan dan tempat melahirkan kurang bervariasi di dalam desa/kelurahan ( $r o h=0,33$ dan $r o h=0,34)$.

Masih terdapat ibu yang melahirkan bayi dengan berat yang rendah (BBLR) yaitu hampir lima persen. Lebih dari $20 \%$ ibu yang berat badan bayinya tidak ditimbang waktu lahir yaitu ibu yang sebagian besar melahirkan di rumah dan persalinannya ditolong oleh petugas non kesehatan, kondisi ini cukup bervariasi di dalam desa (roh=0,19).

Berdasarkan distribusi frekuensi pemberian ASI pertama kali diketahui bahwa rata-rata ibu memberikan ASI untuk pertama kalinya di awal hari kedua $(25,15$ jam) setelah melahirkan dengan median 3 jam. Besar desain efek adalah 4,89 dan nilai ROH 0,22 menunjukkan bahwa waktu pemberian ASI pertama bervariasi di dalam desa/kelurahan. Proporsi ibu yang memberikan ASI dalam satu jam pertama setelah melahirkan sebesar $38,28 \%$ dan ibu yang memberikan ASI lebih dari satu jam pertama setelah melahirkan yaitu $61,72 \%$.

Analisis bivariabel menunjukkan faktor ibu yang berhubungan bermakna dengan pemberian ASI dalam satu jam pertama setelah melahirkan adalah kehamilan yang diinginkan, akses terhadap radio, dan akses terhadap televisi. Faktor pelayanan kesehatan yaitu tenaga periksa, tempat periksa dan juga berat lahir berhubungan dengan pemberian ASI dalam satu jam pertama setelah melahirkan. Variabel yang masuk sebagai kandidat model multivariabel adalah yang mempunyai nilai $p \leq 0,25$ yaitu umur ibu, kehamilan yang diinginkan, daerah tempat tinggal, akses radio, akses televisi, pendidikan suami, tenaga periksa, tempat periksa, penolong dan berat lahir. Variabel tempat melahirkan berdasarkan pertimbangan substansi maka diikutkan dalam analisis selanjutnya.

Selanjutnya analisis data dilanjutkan dengan analisis multivariabel dengan menggunakan regresi logistik multivariat. Strategi pemilihan variabel dengan menggunakan HWF Model (Hierarchically Well Formulated Model). Model akhir yang diperoleh dapat dilihat pada tabel 1.

Besarnya kemungkinan ibu untuk dapat memberikan ASI dalam satu jam pertama berdasarkan daerah tempat tinggal ditentukan menurut tenaga periksa hamil karena adanya interaksi diantara keduanya. Demikian juga kemungkinan berdasarkan kehamilan yang diinginkan ditentukan menurut tenaga periksa hamil karena kehamilan yang diinginkan berinteraksi dengan tenaga periksa hamil. Kemungkinan ibu berdasarkan penolong persalinan ditentukan menurut berat lahir karena keduanya berinteraksi untuk menentukan besarnya kemungkinan berdasarkan tenaga periksa hamil ditentukan menurut daerah tempat tinggal dan kehamilan yang diinginkan. Untuk lebih jelasnya besarnya kemungkinan masing - masing faktor dijelaskan pada tabel 2 .

Berdasarkan daerah tempat tinggal, ibu yang periksa hamil dengan tenaga non kesehatan mempunyai kemungkinan untuk dapat memberikan ASI dalam satu jam pertama setelah melahirkan pada ibu yang tinggal di kota adalah 2,10 kali dibandingkan dengan ibu di desa. Pada

Tabel 1. Model Akhir Hubungan Pemberian ASI Satu Jam Pertama dengan Faktor Ibu, Pelayanan Kesehatan, dan Faktor Bayi

\begin{tabular}{|c|c|c|c|c|c|}
\hline Variabel & - & $\begin{array}{l}\text { Odds } \\
\text { Ratio }\end{array}$ & SE & $\begin{array}{l}\text { P uji } \\
\text { Wald }\end{array}$ & 95\% CI OR \\
\hline \multicolumn{6}{|l|}{ Daerah } \\
\hline Perkotaan & 0,74 & 2,10 & 0,98 & 0,110 & $0,84-5,23$ \\
\hline \multicolumn{6}{|l|}{ Kehamilan yang diinginkan } \\
\hline Kehamilan diinginkan & 1,65 & 5,19 & 2,24 & 0,000 & $2,22-12,1$ \\
\hline \multicolumn{6}{|l|}{ Tenaga periksa hamil } \\
\hline Tenaga kesehatan & 1,20 & 3,32 & 2,22 & 0,073 & $0,90-12,3$ \\
\hline Tidak periksa & 0,95 & 2,60 & 1,14 & 0,030 & $1,09-6,15$ \\
\hline \multicolumn{6}{|l|}{ Penolong persalinan } \\
\hline Tenaga kesehatan & 1,08 & 2,94 & 1,46 & 0,030 & $1,11-7,80$ \\
\hline \multicolumn{6}{|l|}{ Akses terhadap radio } \\
\hline Akses baik & $-0,21$ & 0,81 & 0,09 & 0,053 & $0,66-1,00$ \\
\hline \multicolumn{6}{|l|}{ Berat lahir } \\
\hline Berat lahir normal & 1,43 & 4,19 & 1,83 & 0,001 & $1,78-9,88$ \\
\hline Berat lahir tidak ditimbang & 1,45 & 4,26 & 1,75 & 0,000 & $1,90-9,56$ \\
\hline \multicolumn{6}{|l|}{ Daerah"tenaga periksa } \\
\hline Tenaga kesehatan & $-0,83$ & 0,43 & 0,21 & 0,081 & $0,17-1,11$ \\
\hline Tidak periksa & $-2,11$ & 0,12 & 0,08 & 0,003 & $0,03-0,48$ \\
\hline \multicolumn{6}{|l|}{ Berat lahir*penolong } \\
\hline BB tdk ditimbang*penolong & $-1,26$ & 0,28 & 1,83 & 0,028 & $0,09-0,87$ \\
\hline BB Normal*penolong & $-1,22$ & 0,29 & 0,15 & 0,017 & $0,11-0,80$ \\
\hline \multicolumn{6}{|l|}{ Kehamilan*tenaga periksa } \\
\hline Tenaga kesehatan & $-1,43$ & 0,24 & 0,11 & 0,001 & $0,10-0,57$ \\
\hline Tidak periksa & $-1,53$ & 0,22 & 0,15 & 0,024 & $0,06-0,81$ \\
\hline
\end{tabular}


ibu yang periksa hamil dengan tenaga kesehatan, kemungkinan untuk dapat memberikan ASI dalam satu jam pertama setelah melahirkan pada ibu yang tinggal di kota adalah sebesar 0,9 kali dibandingkan dengan ibu di desa. Sedangkan pada ibu yang tidak periksa hamil, kemungkinan untuk dapat memberikan ASI dalam satu jam pertama setelah melahirkan lebih besar pada ibu yang tinggal di desa yaitu 4 kali $(1 / 0,25)$ dari ibu yang tinggal di kota.

Ibu yang periksa hamil dengan tenaga non kesehatan, kemungkinan untuk dapat memberikan ASI dalam satu jam pertama setelah melahirkan pada ibu yang menginginkan kehamilannya adalah sebesar 5,2 kali dibandingkan dengan ibu yang tidak ingin hamil. Ibu yang periksa hamil dengan tenaga kesehatan, kemungkinan untuk dapat memberikan ASI dalam satu jam pertama setelah melahirkan pada ibu yang menginginkan kehamilannya adalah sebesar 1,25 kali dibandingkan dengan ibu yang tidak ingin hamil. Ibu yang tidak periksa hamil, kemungkinan untuk dapat memberikan ASI dalam satu jam pertama setelah melahirkan pada ibu yang menginginkan kehamilannya adalah sebesar 1,13 kali dibandingkan dengan ibu yang tidak ingin hamil.

Ibu yang tinggal di perkotaan dan menginginkan kehamilannya, maka kemungkinan untuk dapat memberikan ASI dalam satu jam pertama setelah melahirkan pada ibu yang periksa hamil kepada tenaga kesehatan adalah sebesar 1,14 kali dibandingkan dengan ibu yang periksa kepada tenaga non kesehatan. Pada kondisi yang sama, besarnya kemungkinan untuk dapat memberikan ASI dalam satu jam pertama setelah melahirkan pada ibu yang periksa kepada tenaga non kesehatan adalah sebesar 3,4 kali $(1 / 0,29)$ jika dibandingkan dengan ibu yang tidak periksa hamil.

Ibu yang tinggal di perkotaan dan tidak menginginkan kehamilannya, maka kemungkinan untuk dapat memberikan ASI dalam satu jam pertama setelah melahirkan pada ibu yang periksa hamil kepada tenaga non kesehatan adalah sebesar 4,5 kali $(1 / 0,22)$ dibandingkan dengan ibu yang periksa kepada tenaga kesehatan. Pada kondisi yang sama, besarnya kemungkinan untuk dapat memberikan ASI dalam satu jam pertama setelah melahirkan pada ibu yang periksa hamil dengan tenaga non kesehatan adalah sebesar 20 kali $(1 / 0,05)$ dibandingkan dengan ibu yang tidak periksa hamil.

Ibu yang tinggal di pedesaan dan menginginkan kehamilannya, maka kemungkinan untuk dapat memberikan ASI dalam satu jam pertama setelah melahirkan pada ibu yang periksa hamil kepada tenaga non kesehatan hampir 2 kali $(1 / 0,54)$ dibandingkan dengan ibu yang periksa kepada tenaga kesehatan. Pada kondisi yang sama, besarnya kemungkinan untuk dapat memberikan ASI dalam satu jam pertama setelah melahirkan pada ibu yang periksa dengan tenaga non kesehatan adalah 7 kali
Tabel 2. Besarnya Kemungkinan untuk Dapat Memberikan ASI dalam Satu Jam Pertama Berdasarkan Kondisi Variabel Lain

\begin{tabular}{|c|c|}
\hline Variabel & Odds Ratio \\
\hline \multicolumn{2}{|l|}{ EFEK DAERAH } \\
\hline \multicolumn{2}{|c|}{ 1. Pada periksa dengan tenaga kesehatan } \\
\hline Perkotaan & $\mathrm{OR}=\mathrm{e}^{0,74+(-0,83 \times 1)}=0,91$ \\
\hline \multicolumn{2}{|c|}{ 2. Pada periksa dengan tenaga non kesehatan } \\
\hline Perkotaan & $\mathrm{OR}=\mathrm{e}^{0,74+(-0,83 \times 0)}=2,10$ \\
\hline \multicolumn{2}{|c|}{ 3. Pada yang tidak periksa hamil } \\
\hline Perkotaan & $\mathrm{OR}=\mathrm{e}^{0,74+(-2,11)}=0,25$ \\
\hline \multicolumn{2}{|c|}{ EFEK KEHAMILAN YANG DIINGINKAN } \\
\hline \multicolumn{2}{|c|}{ 1. Pada periksa dengan tenaga kesehatan } \\
\hline Kehamilan diinginkan & $\mathrm{OR}=\mathrm{e}^{1,65+(-1,43 \times 1)}=1,25$ \\
\hline \multicolumn{2}{|c|}{ 2. Pada periksa dengan tenaga non kesehatan } \\
\hline Kehamilan diinginkan & $\mathrm{OR}=\mathrm{e}^{1,65+-(1,43 \times 0)}=5,20$ \\
\hline \multicolumn{2}{|c|}{ 3. Pada yang tidak periksa hamil } \\
\hline Kehamilan diinginkan & $\mathrm{OR}=\mathrm{e}^{1,65+(-1,53)}=1,13$ \\
\hline \multicolumn{2}{|c|}{ EFEK TENAGA PERIKSA HAMIL } \\
\hline \multicolumn{2}{|c|}{ 1. Pada perkotaan dan ingin hamil } \\
\hline Tenaga kesehatan & $\mathrm{OR}=\mathrm{e}^{0,74+1,65+(-0,83)+(-1,43)}=1,14$ \\
\hline Tidak periksa & $\mathrm{OR}=\mathrm{e}^{0,74+1,65+(-2,11)+(-1,53)}=0,29$ \\
\hline \multicolumn{2}{|c|}{ 2. Pada perkotaan dan tidak ingin hamil } \\
\hline Tenaga kesehatan & $\mathrm{OR}=\mathrm{e}^{0,74+0+(-0,83)+(-1,43)}=0,22$ \\
\hline Tidak periksa & $\mathrm{OR}=\mathrm{e}^{0,74+0+(-2,11)+(-1,53)}=0,05$ \\
\hline \multicolumn{2}{|c|}{ 3. Pada pedesaan dan ingin hamil } \\
\hline Tenaga kesehatan & $\mathrm{OR}=\mathrm{e}^{0+1,65+(-0,83)+(-1,43)}=0,54$ \\
\hline Tidak periksa & $\mathrm{OR}=\mathrm{e}^{0+1,65+(-2,11)+(-1,53)}=0,14$ \\
\hline \multicolumn{2}{|c|}{ 4. Pada pedesaan dan tidak ingin hamil } \\
\hline Tenaga kesehatan & $\mathrm{OR}=\mathrm{e}^{0+0+(-0,83)+(-1,43)}=0,10$ \\
\hline Tidak periksa & $\mathrm{OR}=\mathrm{e}^{0+0+(-2,11)+(-1,53)}=0,02$ \\
\hline \multicolumn{2}{|l|}{ EFEK BERAT LAHIR } \\
\hline \multicolumn{2}{|c|}{ 1. Pada penolong tenaga kesehatan } \\
\hline Berat lahir normal & $\mathrm{OR}=\mathrm{e}^{1,43+(-1,22)}=1,23$ \\
\hline Berat tidak ditimbang & $\mathrm{OR}=\mathrm{e}^{1,45+(-1,26)}=1,21$ \\
\hline \multicolumn{2}{|c|}{ 2. Pada penolong tenaga non kesehatan } \\
\hline Berat lahir normal & $\mathrm{OR}=\mathrm{e}^{1,43+(-1,22 \times 0)}=4,18$ \\
\hline Berat tidak ditimbang & $\mathrm{OR}=\mathrm{e}^{1,45+(-1,26 \times 0)}=4,26$ \\
\hline
\end{tabular}

jika dibandingkan ibu yang tidak periksa hamil.

Ibu yang tinggal di pedesaan dan tidak menginginkan kehamilannya, maka kemungkinan untuk dapat memberikan ASI dalam satu jam pertama setelah melahirkan pada ibu yang periksa hamil kepada tenaga non kesehatan adalah 10 kali dibandingkan dengan ibu yang periksa kepada tenaga kesehatan. Pada kondisi yang sama, besarnya kemungkinan untuk dapat memberikan ASI dalam satu jam pertama setelah melahirkan pada ibu yang periksa dengan tenaga non kesehatan adalah 50 kali jika dibandingkan dengan ibu yang tidak periksa hamil.

Akses radio berhubungan bermakna dengan pemberian ASI dalam satu jam pertama. Kemungkinan untuk memberikan ASI dalam satu jam pertama pada ibu yang mempunyai akses kurang baik terhadap media radio adalah 1,2 kali dibandingkan ibu yang aksesnya baik.

Berat lahir berhubungan dengan pemberian ASI dalam satu jam pertama. Hubungan berat lahir dengan pemberian ASI dalam satu jam pertama sangat dipengaruhi oleh penolong persalinan karena ada interaksi antara keduanya. Ibu-ibu yang persalinannya ditolong oleh tenaga kesehatan, kemungkinan untuk dapat memberikan ASI dalam satu jam pertama setelah melahirkan 
pada ibu yang melahirkan bayi dengan berat normal sebesar 1,23 kali dibandingkan ibu yang melahirkan bayi BBLR, dan kemungkinan untuk dapat memberikan ASI dalam satu jam pertama setelah melahirkan pada ibu yang melahirkan bayi tidak ditimbang sebesar 1,25 kali dibandingkan ibu yang melahirkan bayi BBLR.

Ibu-ibu yang persalinannya ditolong oleh tenaga non kesehatan, kemungkinan untuk dapat memberikan ASI dalam satu jam pertama setelah melahirkan pada ibu yang melahirkan bayi dengan berat normal sebesar 4,18 kali dibandingkan ibu yang melahirkan bayi BBLR, dan kemungkinan untuk dapat memberikan ASI dalam satu jam pertama setelah melahirkan pada ibu yang melahirkan bayi tidak ditimbang sebesar 4,26 kali dibandingkan ibu yang melahirkan bayi BBLR.

\section{Pembahasan}

Hasil penelitian menunjukkan proporsi pemberian ASI dalam satu jam pertama setelah melahirkan di Indonesia sebesar $38,28 \%$. Masih banyaknya ibu yang memberikan ASI lebih dari satu jam pertama setelah melahirkan (menunda inisiasi ASI) menyebabkan bayi mendapat makanan prelaktal dan konsekuensinya kemampuan bayi mengisap ASI berkurang. Hal ini didukung oleh penelitian Simandjuntak ${ }^{12}$ yang menyatakan bahwa salah satu faktor yang berhubungan dengan umur pemberian MP-ASI dini adalah inisiasi ASI dimana inisiasi yang terlambat berisiko 5,4 kali untuk menyebabkan pemberian MP-ASI dini dibandingkan inisiasi ASI segera. Hasil yang sama juga didapat pada penelitian Fikawati dan Syafiq ${ }^{8}$ yang dilakukan di Jawa Barat dan Jawa Timur bahwa ibu yang tidak memberikan ASI segera dalam 30 menit setelah melahirkan (immediate breastfeeding) berisiko memberikan makanan/minuman pralaktal 1,8 sampai 5,3 kali lebih besar dibandingkan ibu yang immediate breastfeeding. Jenis makanan/minuman yang diberikan kepada bayi meliputi susu formula, madu, air putih, air gula, pisang, dan lainnya (seperti nasi papak).

Pemberian makanan/minuman pada bayi baru lahir dapat menyebabkan terjadinya diare jika penyediaannya tidak higienis. ${ }^{13}$ Di samping itu pemberian prelacteal feeding seperti air gula juga dapat menghilangkan rasa haus bayi dan menjadikan bayi malas menetek. ${ }^{14}$

Daerah tempat tinggal berhubungan dengan pemberian ASI dalam satu jam pertama dan sangat dipengaruhi oleh tenaga periksa hamil. Hasil yang menunjukkan bahwa ibu di perkotaan dan periksa hamil dengan tenaga kesehatan justru kemungkinan untuk dapat memberikan ASI dalam satu jam pertama lebih kecil, hal ini dapat disebabkan kurangnya peranan tenaga kesehatan dalam memberikan informasi mengenai bagaimana manajemen menyusui yang baik pada waktu periksa hamil.
Ibu yang tidak periksa hamil dan tinggal di pedesaan memiliki kemungkinan paling besar untuk dapat memberikan ASI dalam satu jam pertama, hal ini dapat disebabkan karena kurangnya peran tenaga kesehatan dalam memberikan informasi yang benar kepada ibu mengenai manajemen laktasi yang baik. Di samping itu ibu yang tinggal di desa adalah ibu dengan sosial ekonomi yang rendah dan tidak mempunyai daya beli terhadap susu formula. Hubungan ibu-anak dalam ikatan yang sehat dan mesra tetap hidup di daerah pedesaan dimana menyusui merupakan kebiasaan yang umum dalam keluarga. ${ }^{15}$ Ibu pada golongan ini sebagian besar melahirkan di rumah. Pada persalinan di rumah, ibu dan bayi biasanya tidak dipisah dan persalinan di rumah kurang terpapar dengan gencarnya promosi susu formula. Berdasarkan penelitian di Bogor menunjukkan sebagian besar ibu menyatakan bahwa $76 \%$ promosi susu formula bersumber pada sarana pelayanan kesehatan. ${ }^{7}$

Kehamilan yang diinginkan mempunyai hubungan yang bermakna dengan pemberian ASI dalam satu jam pertama. Ibu yang periksa hamil dengan tenaga non kesehatan dan menginginkan kehamilannya justru mempunyai kemungkinan yang lebih besar untuk dapat memberikan ASI dalam satu jam pertama dibandingkan ibu yang menginginkan kehamilan dan periksa dengan tenaga kesehatan. Hal ini dapat disebabkan karena motivasi dan peranan tenaga kesehatan yang kurang dalam memberikan informasi mengenai pemberian ASI yang benar dan tepat sewaktu ibu melakukan periksa hamil. Penyebab lain adalah dari analisis lebih rinci menunjukkan bahwa ibu yang periksa dengan tenaga non kesehatan sebagian besar melahirkan di rumah dimana paparan promosi susu formula lebih sedikit, ibu dan bayi tidak terpisah setelah melahirkan dan daya beli terhadap susu formula rendah karena kondisi sosial ekonomi yang rendah.

Program utama yang dapat digunakan untuk merencanakan kehamilan adalah program keluarga berencana (KB). Selanjutnya perlu dilakukan sosialisasi program keluarga berencana kepada seluruh pasangan usia subur melalui kegiatan penyuluhan serta meningkatkan keterjangkauan alat kontrasepsi.

Akses terhadap media dalam hal ini media elektronik yaitu radio mempunyai hubungan yang bermakna dengan pemberian ASI dalam satu jam pertama. Hasil penelitian yang menunjukkan bahwa ibu yang aksesnya kurang baik terhadap radio justru kemungkinan untuk dapat memberikan ASI dalam satu jam pertama lebih besar dapat disebabkan karena penilaian keterpaparan dengan media radio disini kurang menggambarkan apakah ibu juga terpapar dengan informasi mengenai kesehatan terutama pemberian ASI karena akses yang dinilai hanya frekuensi saja, dan tidak mencakup materi atau informasi kesehatan apa yang didapatkan. Penyebab lain adalah bahwa 
sebagian besar siaran radio masih didominasi dengan acara yang bersifat hiburan, sedangkan pemberian informasi mengenai kesehatan masih sangat kurang. Komposisi siaran radio tergantung pada misi radio tersebut. Radio milik pemerintah memiliki komposisi siaran untuk penerangan $40 \%$, pendidikan (kesehatan,agama, dan pengetahuan populer) sebesar $30 \%$, hiburan $20 \%$, dan iklan $10 \%$. Siaran radio swasta sedikit berbeda yaitu untuk penerangan $20 \%$, pendidikan $25 \%$, hiburan $40 \%$, dan iklan $15 \% .16$

Tenaga periksa hamil berhubungan bermakna dengan pemberian ASI dalam satu jam pertama. Ibu yang periksa hamil dengan tenaga non kesehatan dan tinggal di pedesaan serta tidak menginginkan kehamilannya mempunyai kemungkinan paling besar untuk dapat memberikan ASI dalam satu jam pertama yaitu sampai 50 kali dibandingkan ibu yang tidak periksa hamil.

Ibu yang melakukan periksa hamil dengan tenaga non kesehatan maupun ibu yang tidak melakukan periksa hamil biasanya berada pada tingkat sosial ekonomi yang rendah. Alasan ibu tidak periksa hamil atau periksa dengan tenaga non kesehatan karena jika periksa dengan tenaga kesehatan memerlukan biaya yang tinggi dibanding periksa pada dukun, di samping itu ibu merasa sehat dan tidak bermasalah dengan kehamilannya. Ibu dengan tingkat sosial ekonomi yang rendah mempunyai daya beli yang rendah terhadap susu formula dibandingkan ibu dari sosial ekonomi yang tinggi.

Pada ibu yang periksa hamil dengan tenaga kesehatan, kemungkinan untuk dapat memberikan ASI dalam satu jam pertama justru lebih kecil daripada ibu yang periksa dengan tenaga non kesehatan. Hal ini menunjukkan bahwa tenaga kesehatan kurang berperan dalam memberikan informasi mengenai pemberian ASI yang benar pada waktu pemeriksaan kehamilan.

Pada ibu yang sama-sama tinggal di desa dan tidak menginginkan kehamilannya, kemungkinan untuk dapat memberikan ASI dalam satu jam pertama lebih besar pada ibu yang periksa dengan tenaga non kesehatan dibandingkan ibu yang tidak periksa hamil. Hal ini dapat disebabkan karena ibu yang tidak menginginkan kehamilannya akan tetapi melakukan periksa hamil dengan tenaga non kesehatan menunjukkan bahwa ibu memiliki kesadaran lebih baik dan berusaha untuk menjaga kehamilan sesuai dengan kemampuannya daripada ibu yang tidak periksa hamil.

Program pemerintah berkaitan dengan tenaga pemeriksa kehamilan adalah dengan penempatan tenaga dokter PTT di daerah terpencil dan penempatan bidan di desa-desa. Akan tetapi dalam penelitian ini masih dijumpai ibu hamil yang tidak memeriksakan kehamilannya, oleh karena itu perlu upaya untuk meningkatkan kesadaran ibu hamil sendiri untuk memeriksakan kehamilannya serta keaktifan dari petugas dalam memotivasi ibu hamil untuk rutin memeriksakan kehamilannya. Upaya lain yang dapat dilakukan adalah peningkatan pengetahuan dengan pelatihan dan penyegaran secara rutin terhadap petugas kesehatan terutama bidan dan petugas kesehatan di tingkat desa.

Penolong persalinan berhubungan bermakna dengan pemberian ASI dalam satu jam pertama. Hasil ini sejalan dengan penelitian Tjandrarini, ${ }^{17}$ dan penelitian Hasyim $\mathrm{dkk}^{18}$ di Palembang yang menyatakan adanya hubungan bermakna antara penolong persalinan dengan pertama kali pemberian ASI setelah melahirkan.

Penolong persalinan merupakan kunci utama keberhasilan pemberian ASI dalam satu jam pertama setelah melahirkan (immediate bresatfeeding) karena dalam waktu tersebut peran penolong persalinan masih sangat dominan. Apabila penolong persalinan menfasilitasi ibu untuk segera memeluk bayinya maka interaksi ibu dan bayi diharapkan segera terjadi. Dengan immediate breastfeeding ibu semakin percaya diri untuk tetap memberikan ASInya sehingga tidak merasa perlu untuk memberikan makanan/minuman apapun kepada bayi karena bayi bisa nyaman menempel pada payudara ibu atau tenang dalam pelukan ibu segera setelah lahir. ${ }^{8}$

Berat lahir berhubungan bermakna dengan pemberian ASI dalam satu jam pertama dan berinteraksi dengan penolong persalinan. Hasil yang menunjukkan bahwa kemungkinan untuk memberikan ASI dalam satu jam pertama lebih besar pada bayi yang ditolong oleh tenaga non kesehatan maka hal ini dapat disebabkan bahwa ibu yang persalinannya ditolong oleh petugas kesehatan melahirkan bayinya di rumah sakit atau tempat bersalin dimana masih banyak terdapat tata laksana rumah sakit yang kurang mendukung keberhasilan menyusui seperti bayi tidak segera disusui, memberikan makanan prelaktal, gencarnya promosi susu formula.

Pada sebagian besar sarana persalinan pemberian makanan pralaktal sudah menjadi kebiasaan, berupa susu formula, susu sapi, atau air gula. ${ }^{12}$ Hasil penelitian di Bogor menunjukkan bahwa 60\% ibu menyatakan menerima susu formula bayi melalui rumah sakit atau rumah bersalin dan sekitar $40 \%$ ibu menerima hadiah dari perusahaan susu formula untuk bayi. Penelitian ini juga menemukan hasil bahwa $14,8 \%$ bidan menyatakan setuju untuk memberikan susu formula kepada bayi baru lahir. $^{7}$

\section{Kesimpulan}

1. Proporsi pemberian ASI dalam satu jam pertama setelah melahirkan di Indonesia masih rendah.

2. Faktor ibu yang berhubungan dengan pemberian ASI dalam satu jam pertama setelah melahirkan adalah daerah tempat tinggal, kehamilan yang diinginkan dan akses terhadap media radio. Besarnya efek daerah dan efek kehamilan diinginkan terhadap pemberian ASI 
dalam satu jam pertama setelah melahirkan tergantung pada tenaga periksa hamil.

3. Faktor pelayanan kesehatan yang berhubungan dengan pemberian ASI dalam satu jam pertama setelah melahirkan adalah tenaga periksa kehamilan dan penolong persalinan. Besarnya efek tenaga periksa hamil terhadap pemberian ASI dalam satu jam pertama setelah melahirkan tergantung pada daerah tempat tinggal dan kehamilan diinginkan.

4. Faktor bayi yaitu berat lahir berhubungan dengan pemberian ASI dalam satu jam pertama setelah melahirkan. Besarnya efek berat lahir terhadap pemberian ASI dalam satu jam pertama setelah melahirkan tergantung pada penolong persalinan.

5. Faktor yang dominan berhubungan dengan pemberian ASI dalam satu jam pertama setelah melahirkan adalah tenaga periksa hamil.

\section{Saran}

1. Upaya peningkatan pengetahuan dan motivasi petugas kesehatan mengenai pentingnya pemberian ASI segera setelah melahirkan dan ASI eksklusif sehingga dapat lebih memberi perhatian, memberikan informasi yang tepat dan memfasilitasi ibu untuk memberikan ASI secara benar.

2. Meningkatkan pengetahuan ibu dan calon ibu mengenai pentingnya pemberian ASI segera setelah melahirkan dan ASI eksklusif melalui kegiatan penyuluhan sehingga diharapkan semua ibu dapat memberikan ASI secara benar dan tepat.

3. Peningkatan jumlah dan kualitas serta pemerataan penempatan tenaga kesehatan. Masih banyaknya ibu lebih memilih melahirkan di rumah dan persalinannya ditolong oleh tenaga non kesehatan, maka perlu dilakukan upaya peningkatan pendampingan persalinan oleh tenaga tenaga kesehatan.

4. Upaya penyuluhan untuk memasyarakatkan program keluarga berencana kepada wanita usia subur dan ibu hamil sehingga dapat merencanakan kehamilannya dengan baik serta meningkatkan keterjangkauan terhadap pelayanan keluarga berencana.

5. Departemen Kesehatan khususnya yang berwenang dalam menentukan kebijakan rumah sakit agar dapat segera menerapkan kebijakan yang telah dibuat mengenai Sepuluh Langkah Menuju Keberhasilan Menyusui pada tempat-tempat persalinan, baik swasta maupun pemerintah serta memberikan sanksi hukum yang jelas dan tegas bagi yang melanggar peraturan tersebut.

6. Upaya peningkatan pengetahuan masyarakat melalui media elektronik dengan cara menyisipkan pesanpesan mengenai pentingnya pemberian ASI segera mungkin dan ASI eksklusif dalam siaran radio.

7. Perlu peningkatan upaya kerjasama lintas program dan lintas sektor dalam rangka peningkatan pemberian ASI segera dan ASI eksklusif.

8. Bagi pelaksana SDKI, perlu penambahan bahan pertanyaan untuk SDKI selanjutnya tentang alasan ibu kenapa tidak segera menyusui bayinya setelah lahir, kontraindikasi menyusu dan menyusui.

\section{Daftar Pustaka}

1. Badan Pusat Statistik, BKKBN, Departemen Kesehatan (2004). Survei Demografi dan Kesehatan Indonesia 2002-2003. Jakarta.

2. The World Factbook (2003). Infant mortality rate, http ://www.cia.gov/publication/factbook, diakses Februari 2005.

3. Departemen Kesehatan. Laporan studi mortalitas 2001: pola penyakit penyebab kematian di Indonesia. Jakarta: Badan Penelitian Dan Pengembangan Kesehatan, Departemen Kesehatan RI; 2002

4. Moehji, Sjahmien. Pemeliharaan gizi bayi dan balita. Jakarta: Bhratara Karya Aksara; 1988.

5. Lawrence, R. Breastfeeding a guide for the medical profession, $5^{\text {th }} \mathrm{Ed}$, Mosby-Inc, USA; 1994.

6. Whorthington-Roberts, B.S., et al. Nutrition in pregnancy and lactation, $5^{\text {th }}$ Ed, Mosby-Inc, USA; 1993.

7. Departemen Kesehatan. Manajemen laktasi, buku pegangan bagi petugas kesehatan. Jakarta: Direktorat Jenderal Pembinaan Kesehatan Masyarakat, Departemen Kesehatan RI; 2002.

8. Fikawati, Sandra\& Syafiq, Ahmad. Hubungan antara menyusui segera (immediate breastfeeding) dan pemberian ASI eksklusif sampai dengan empat bulan. Jurnal Kedokteran Trisakti. Mei - Agustus; 22 (2); 2003.

9. Irawati, Anies dkk. Pola inisiasi dan faktor-faktor yang berhubungan dengan keterlambatan inisiasi ASI di Indonesia, Journal Of Indonesian Nutrition Association, Jakarta; 1996.

10. Manuaba, Ida Bagus Gede. Ilmu kebidanan, penyakit kandungan, dan keluarga berencana untuk pendidikan bidan. Jakarta: Penerbit Buku Kedokteran ECG; 1998.

11. Roesli, Utami. Mengenal ASI eksklusif, Jakarta: Trubus Agriwidya; 2000

12. Simandjuntak, Dahlia. Faktor-faktor yang berhubungan dengan pem berian makanan pendamping ASI dini pada bayi di Kecamatan Pasar Rebo, Kotamadya Jakarta Timur Tahun 2001. [Tesis]. Jakarta: Program Pascasarjana Fakultas Kesehatan Masyarakat Universitas Indonesia; 2002.

13. Wiryo, Hananto. Dampak pemberian pisang (musa paradisiaca) terhadap timbulnya penyumbatan saluran pencernaan neonatus, Majalah Kedokteran Indonesia, 48 (9), September 2004; 1998.

14. Suradi, Rulina . Peranan lingkungan untuk menunjang keberhasilan laktasi, dalam Perinasia (editor) bungai rampai menyusui dan rawat gabung. Jakarta: Perkumpulan Perinatologi Indonesia; 1986.

15. Soysa, Priyani E. Keuntungan-Keuntungan menyusui dari sudut pandang negara sedang berkembang dalam PERDHAKI (alih bahasa) breastfeeding and health. Jakarta: Departemen Kesehatan/Direktorat Bina Gizi Masyarakat UNICEF dan PERDHAKI; 1981.

16. Ahmad. Penggunaan radio siaran sebagai media pendidikan kesehatan oleh institusi kesehatan di Kabupaten Dati II Lebak Tahun 1996/1997. [Skripsi]. Jakarta: Fakultas Kesehatan Masyarakat Universitas Indonesia; 1998

17. Tjandrarini, Dwi Hapsari dkk.Telaah faktor karakteristik ibu dan pelayanan kesehatan yang berhubungan dengan pemberian kolostrum lebih dari satu jam pertama setelah melahirkan (analisis data sekunder survei demografi dan kesehatan Indonesia 1997), Laporan Penelitian, Badan Penelitian dan pengembangan Kesehatan Pusat Penelitian Ekologi Kesehatan, Departemen Kesehatan RI, Jakarta; 2000.

18. Hasyim, dkk. Pemberian air susu ibu (ASI) eksklusif wanita pekerja perusahaan swasta Kota Palembang, Majalah Obstet Ginekologi Indonesia, 24, (4); Oktober 2000. 